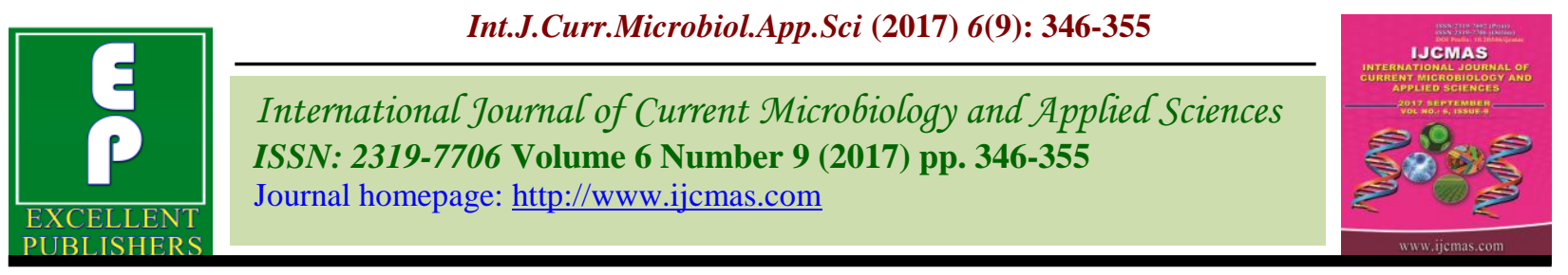

Original Research Article

https://doi.org/10.20546/ijcmas.2017.609.044

\title{
Study on Export and Retail Price Behavior of Coffee Seed in India: An Econometric Analysis
}

\author{
N. Ashoka ${ }^{1^{*}}$, Balachandra K. Naik ${ }^{2}$ and G. Anupama ${ }^{3}$ \\ ${ }^{1}$ Department of Agricultural Economics, College of Horticulture, Munirabad, \\ Koppal, Karnataka-583233, India \\ ${ }^{2}$ Department of Agribusiness Management, College of Agriculture, UAS, \\ Dharwad-580005, India \\ ${ }^{3}$ Horticulture Training Centre, Munirabad, Koppal, Karnataka-583233, India \\ *Corresponding author
}

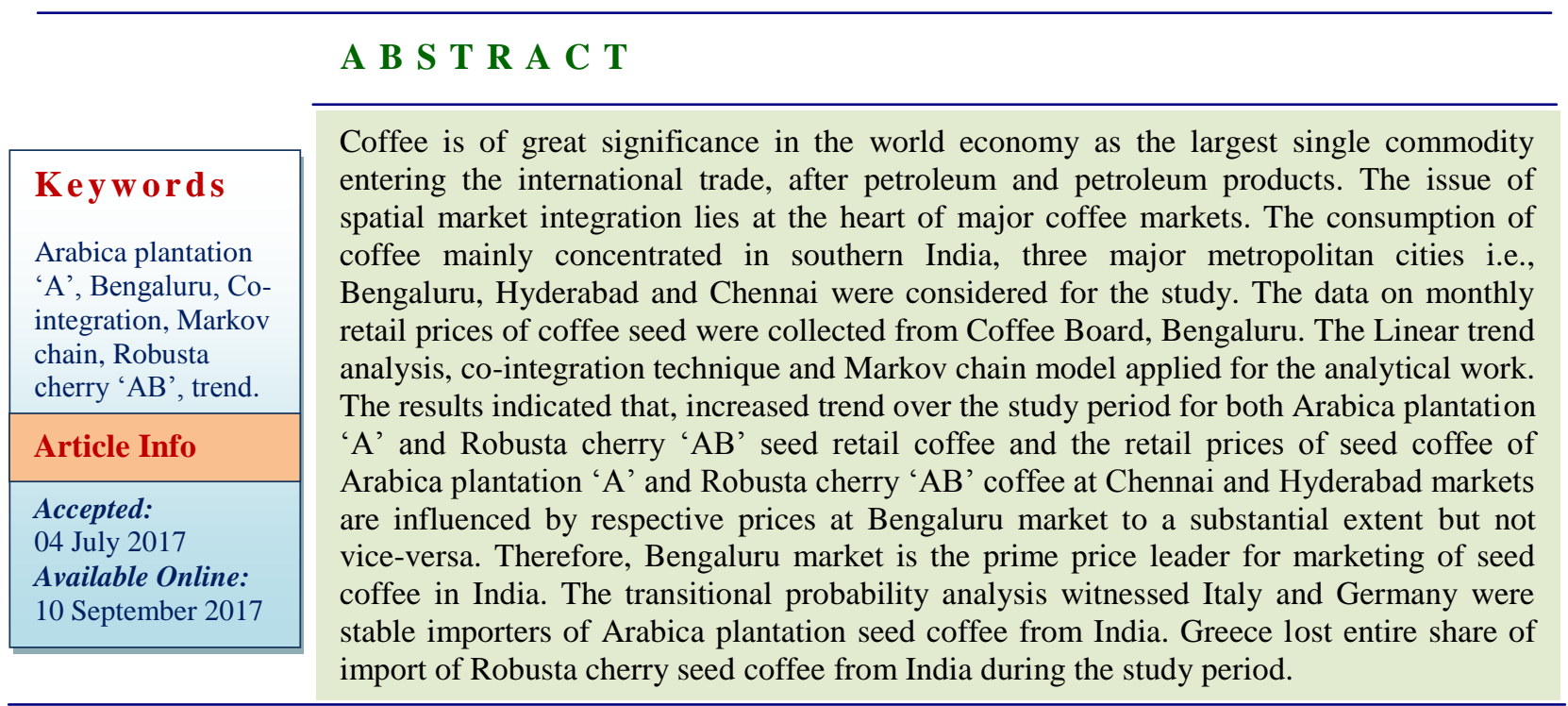

\section{Introduction}

Coffee, nicknamed as 'Islamic milk' and 'sage's milk', had produced quotations from poets and famous jests. Karnataka accounts for 56.1 per cent of the planted area, accounting about 72 per cent of the Indian production. Kerala with 20.7 per cent and Tamil Nadu with 7.7 per cent of planted area account for 20.2 and 5.6 per cent of Indian coffee production, respectively. In Karnataka state, there are three major coffee growing districts viz., Chikmagalur, Kodagu and
Hassan. In India, coffee is basically a small farmer's activity where 98.8 per cent of the holdings are less than 10 hectare size (200708). About two thirds of the area is cultivated by small holders, who contribute about 70 per cent to the total production. Coffee industry in India has witnessed a major crisis caused by falling coffee prices in the last decade for both Arabica and Robusta. The issue of spatial market integration lies at the heart of many contemporary debates concerning 
market liberalization, price policy and parastatal reforms in developing countries. Without spatial integration of market, price signals will not be transmitted among spatially separated markets.

Coffee prices have been highly fluctuating over the years. For understanding the importance of market interrelationships, several studies have attempted to develop measures of market integration, relied on correlation between prices in the pairs of markets. But co-integration test gives the clear picture of market integration of different markets which spatially separated. In this regard, this study through the light on trends and relationship of retails prices of coffee seeds in major domestic markets in India.

\section{Materials and Methods}

For this study, monthly seed retail coffee price of Arabica plantation ' $A$ ' and Robusta cherry 'AB' were collected from January 2000 to December 2015 from Coffee Board of India, Bengaluru. The monthly seed retail coffee prices of Bengaluru, Hyderabad and Chennai markets were considered as domestic seed retail markets for both Arabica plantation 'A' and Robusta cherry 'AB' types.

This was done to analyze the trend and examine the market integration of prices in different wholesale markets.

\section{Analytical framework}

\section{Liner trend analysis}

For estimating the long-run trend in prices of coffee in different retail markets, the method of ordinary least squares estimate was employed. This method of ascertaining the trend in a series of data involves estimating the coefficient of intercept (a) and slope (b) in the linear functional form. The equation adopted for this purpose was specified as follows,

$Y_{t}=a+b X+e$

Where,

$\mathrm{Y}_{\mathrm{t}}=$ Trend values at time $\mathrm{t}$

$\mathrm{X}=$ Period in years

$\mathrm{a}=$ intercept parameter

$\mathrm{b}=$ slope parameter

$\mathrm{e}=$ Error

Trend in prices for the selected markets were computed and compared. The goodness of fit of trend line to the data was tested by computing the coefficient of determinations which is denoted by $\mathrm{R}^{2}$.

\section{Co-integration analysis}

Two prices series belongs to spatially separated markets are said to be integrated if there is exists a long-term equilibrium relationship between them. In the present study co-integration method was adapted with the use of Eviews 7 software to study the market integration for prices of the selected markets. To carry out the analysis, data was made stationary mean that the process of generating the data is in equilibrium around a constant value and that the variance around the mean remains constant over a time. If mean changes over time and variance is not reasonably constant, then the series is nonstationary. To decide the stationarity or nonstationary of the data, for each the price series ADF test (Augmented Dickey -Fuller Unit root test) has been conducted.

If calculated probability value of respective market in ADF test is less than 0.09 then that market's price data is already stationary. But if the ADF values are greater than 0.09, data is subjected to $1^{\text {st }}$ order differencing or $2^{\text {nd }}$ order differencing until it becomes stationery 
(as specified by probability value less than 0.09).

\section{Granger causality test}

Bivariate Granger causality tests involve using regression analysis to provide an indication of whether lagged values of one variable $\mathrm{x}$ can help predict current values of another variable $y$. The approach involves seeing how much of the current value of $y$ can be explained by past values of $y$ and then to see whether adding lagged values of $\times$ can improve the explanation of $y$. Hence, variable $\mathrm{y}$ is said to be Granger caused by $\mathrm{x}$ if $\mathrm{x}$ helps in the prediction of $y$, or equivalently if the coefficients on the lagged $x$ 's are statistically significant.

Finally Vector Autoregression Estimates are calculated for all the markets. The VER estimates will provide the short term cointegration with in the markets and between the markets which will be expressed in percentage. The T-statistics are calculated to know the significance of the markets within them and also between markets, which will be decided on the basis of T-statistics values. If the T-statistics values are greater than 1.7 then the integration values are considered as significant otherwise they are non-significant and only significant values will be considered for drawing the inferences.

\section{Markov chain process}

The structural changes in the share of Arabica plantation coffee export to different destinations analyzed through first order Markov model. Central to Markov chain analysis is the estimation of transitional probability matrix, ' $\mathrm{P}$ '. The element ' $\mathrm{P}_{\mathrm{ij}}$ ' of this matrix indicates the probability that export will switch from country I to j, with the passage of time. The diagonal element ' $\mathrm{P}_{\mathrm{ij}}$ ' $(\mathrm{i}=\mathrm{j})$ measures the probability the export share of that country will be retained. An examination of this matrix will indicate the stability of particular export destination of India. Further, the export to particular country was considered to be a random variable, which depends only on its past export to that country and following a first order Markov model, it can be denoted algebraically as,

$\mathrm{E}_{\mathrm{jt}}=\sum_{i=1}^{n}\left[E i_{t-1}\right] P_{i j}+e_{j t}$

Where,

$\mathrm{E}_{\mathrm{jt}}=$ exports from India to the $\mathrm{j}^{\text {th }}$ country in the year $\mathrm{t}$

$E_{i t-1}=$ exports of $i^{\text {th }}$ country during the year $t-1$

$P_{i j}=$ the probability that exports will shift from $i^{\text {th }}$ country to $j^{\text {th }}$ country

$\mathrm{e}_{\mathrm{jt}}=$ the error term which is statistically independent of $\mathrm{E}_{\mathrm{it}-1}$

$\mathrm{n}=$ the number of importing countries

The transitional probabilities $\mathrm{P}_{\mathrm{ij}}$, which can be

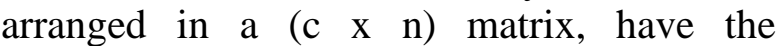
following properties.

$\sum_{i=1}^{n} P_{I j}=1$ And $0 \leq \mathrm{P}_{\mathrm{Ij}} \leq 1$

Thus, the expected export share of each country during period ' $t$ ' is obtained by multiplying the exports to these countries in the previous period ( $t-1)$. Similarly, the future export share of each of the importing country can also be estimated. The transitional probability matrix was estimated in the linear programming (LP) frame work by a method referred to as minimization of mean absolute deviation. The LP formulation is stated as 
Min, $\mathrm{OP}^{*}+\mathrm{I} \mathrm{e}$

Subject to

$\mathrm{XP} *+\mathrm{V}=\mathrm{Y}$

$\mathrm{GP}^{*}=1$

$\mathrm{P}^{*} \geq 0$

Where,

$\mathrm{P}^{*}$ is a vector of the probabilities $\mathrm{P}_{\mathrm{Ij}}$

$\mathrm{O}$ is the vector of zeros

I is an appropriately dimensional vectors of areas

$\mathrm{e}$ is the vector of absolute errors

$\mathrm{Y}$ is the proportion of exports to each country.

$\mathrm{X}$ is a block diagonal matrix of lagged values of $\mathrm{Y}$

$\mathrm{V}$ is the vector of errors

$\mathrm{G}$ is a grouping matrix to add the row elements of $\mathrm{P}$ arranged in $\mathrm{P}^{*}$ to unity.

\section{Results and Discussion}

\section{Trends in seed coffee retail prices in major} domestic markets

The table 1 depicts the trend in retail coffee seed prices in domestic markets during 2000 2015. There is an increasing trend in price of retail coffee seed in all the markets during the study period. The annual increase in seed coffee retail price of Arabica plantation 'A' was found to be maximum ( $₹ 167$ per quintal per annum) in Hyderabad market followed by Chennai ( $₹ 152.30$ per quintal per annum) and Bengaluru ( $₹ 151.60$ per quintal per annum) markets. In these markets, the contribution of time to change in prices was to an extent of
84,83 and 81 per cent respectively. The price of Robusta cherry 'AB', increased at ₹ 86.50 per quintal annual in Hyderabad market which is followed by Bengaluru ( $₹ 79.81$ per quintal per annum) and Chennai ( $₹ 76.58$ per quintal per annum).

Coffee seeds have been marketed through retailers who purchases coffee beans from the wholesalers. The retail seed prices have shown increasing trend for both varieties of coffee. This is because of more demand for seed coffee in the recent years as promotional activities taken up by the Coffee Board to strengthen domestic consumption for coffee.

Towards this end, the Board participated in Coffee-centric beverages exhibitions in India. The Board also runs 12 India Coffee Houses and Depots in the country. The increase in prices was in same line in all the three major seed coffee retail markets due to integration of these domestic markets with each other. Similar results were reported by Ashoka et al., (2016) for wholesale coffee prices in India. This result is in correlation with the results of tables 2 to 5 where seed coffee prices of Bengaluru retail market were influenced heavily on Hyderabad and Chennai markets.

\section{Integration of domestic seed coffee retail markets}

The result of Augmented Dickey Fuller-Unit root test for retail coffee seed prices of Arabica plantation ' $A$ ' grade coffee are depicted in table 2. The retail price series of seed coffee at Hyderabad market was already stationary which meant that co-integration could not be studied for this market. Hence, retail price series of seed coffee in this market was removed from the analysis. Rest of the price series of the markets i.e., Bengaluru and Chennai were made stationary by taking first difference. Bengaluru market seed coffee 
retail prices granger caused Chennai market seed coffee retail prices, but not vice versa.

As per ADF-Unit root test conducted on price series regarding their stationarity, it was found that the seed coffee retail prices of Arabica plantation ' $A$ ' coffee were found stationary with respect to Hyderabad market in the first instance. Hence, the series was not considered for further analysis as the prices in Hyderabad retail seed market are not influenced by any factor.

The results of granger casualty test indicated (Table 1) that Bengaluru seed coffee retail market prices of Arabica plantation ' $\mathrm{A}$ ' granger cause Chennai market prices but not vice versa. The table indicated that Chennai seed coffee retail markets price does not affect the Bengaluru prices. This clearly indicates the Chennai seed coffee retail markets prices of Arabica plantation ' $A$ ' are the receivers of price signals from Bengaluru market and do not influence on Bengaluru prices. Hence, seed coffee retail markets prices of Arabica plantation ' $A$ ' at Bengaluru to be considered as vital market for policy frame work in domestic markets

The co-integration coefficient was significant with respect to Chennai seed coffee retail market with value of 0.43 as revealed in table 3. One month previous Arabica plantation ' $A$ ' seed coffee retail prices at Bengaluru market influences the present prices of same market to the extent of 32 per cent and 32 per cent variation in present market prices of Arabica plantation ' $A$ ' seed coffee retail seed price in Chennai market was influenced by one month previous seed coffee retail prices of Bengaluru market in positive direction. Likewise one month and two month lagged prices of Chennai seed coffee retail prices affect the present prices of same market to the tune of 22 and 23 per cents respectively in opposite direction.
The table 3 revels that any shocks in seed coffee retail markets prices of Arabica plantation ' $A$ ' coffee at Chennai market would get corrected by itself in 43 per cent of time duration (about 12 days). The table also explains that one month pervious seed coffee retail prices of Arabica plantation 'A' coffee of Bengaluru market would alters the current prices on Bengaluru and Chennai seed coffee retail market prices to the extent of 32 per cent each whereas, current seed coffee retail prices of at Chennai market depends on one and two month previous prices of same market to the extent of 22 and 23 per cent respectively. The overall results of integration of domestic seed coffee retail market prices for Arabica plantation ' $A$ ' coffee proved that these markets are integrated in one direction i.e., Bengaluru prices influencing Chennai and not vice-versa. Ashoka et al., (2016) reported alike pattern of market integration for wholesale coffee prices in India.

Therefore, it is interesting to note that for marketing of Arabica plantation ' $A$ ' seed coffee in domestic markets, seed coffee retail market prices at Bengaluru to be considered as lead prices. Chennai and Hyderabad seed coffee retail markets are the main consumption centers, the demand for coffee in these centers determine the retail coffee seed prices in Bengaluru (Venkatram and Deodhar, 2005). Similarly, Bengaluru is the supply point of coffee in the country, the seed coffee retail prices at Bengaluru market influence on Chennai retail market.

It could be seen from the table 4 that, Bengaluru, Chennai and Hyderabad seed coffee retail price series for Robusta cherry ' $A B$ ' grade were found to be non-stationary and the prices were subjected to first order differencing in order to arrive at stationarity. A birds eye view of the table reveals that the seed coffee retail prices in each of the Bengaluru, Chennai and Hyderabad markets 
influence on the seed coffee retail prices in the other two markets, as revealed by granger causality test.

It is observed from the table 4 that the seed coffee retail prices of Robusta cherry ' $\mathrm{AB}$ ' coffee of Bengaluru market granger cause seed coffee retail prices in other two market, Hyderabad prices granger cause Chennai and vice-versa, as revealed by probability values of granger causality test. In other words, seed coffee retail prices of Robusta cherry ' $\mathrm{AB}$ ' coffee in each markets influence on other two markets. Hence, the seed coffee retail prices in all markets to be considered for framing policies related to prices of Robusta cherry 'AB' coffee in domestic markets.

The co-integration coefficients were significant with respect to all markets with values of 0.19 for Bengaluru, 0.28 for Chennai and 0.25 for Hyderabad seed coffee retail prices as depicted in table 5. Present seed coffee retail prices of Robusta cherry ' $A B$ ' in Chennai markets is influenced by one month previous prices of Chennai market itself to the extent of 28 per cent in opposite direction.

Table.1 Trends in coffee seed retail prices at major domestic markets (2000-2015)

\begin{tabular}{clccc} 
& & & & (₹/q) \\
\hline Coffee type & \multicolumn{1}{c}{ Markets } & Intercept & Slope & $\mathbf{R}^{2}$ \\
\hline \multirow{2}{*}{ Arabica plantation 'A' } & Bengaluru & 2475 & 151.6 & 0.81 \\
& Chennai & 3784 & 152.3 & 0.83 \\
& Hyderabad & 3113 & 167.0 & 0.84 \\
Robusta cherry 'AB' & Bengaluru & 1638 & 79.81 & 0.84 \\
& Chennai & 2364 & 76.58 & 0.84 \\
& Hyderabad & 2049 & 86.50 & 0.83 \\
\hline
\end{tabular}

Table.2 Result of Granger Causality Tests for domestic seed coffee retail markets of Arabica plantation ' $A$ '

\begin{tabular}{cccc}
\hline Null Hypothesis: & Observation & F-Statistic & Probability \\
\hline CHN does not Granger Cause BLR & 192 & 0.68044 & 0.5080 \\
BLR does not Granger Cause CHN & 192 & 22.9554 & 0.0020 \\
\hline
\end{tabular}

Note: 1) BLR-Bengaluru CHN-Chennai 2 2) Hyderabad market retail price series was found to stationary as per the ADF -Unit root test. Hence, the series was not considered for the further analysis.

Table.3 Co-integration for domestic seed coffee retail markets of Arabica plantation 'A' coffee

\begin{tabular}{ccc}
\hline Error Correction & D(BLR) & D(CHN) \\
\hline \multirow{2}{*}{ CointEq1 } & 0.019727 & 0.426046 \\
& {$[0.32277]$} & {$[4.44148]^{*}$} \\
D(BLR(-1)) & 0.324903 & 0.322875 \\
& {$[3.11304]^{*}$} & {$[1.97104]^{*}$} \\
D(BLR(-2)) & 0.142034 & 0.042012 \\
& {$[1.40003]$} & {$[0.26385]$} \\
D(CHN(-1)) & -0.008063 & -0.219944 \\
& {$[-0.12573]$} & {$[-2.18505]^{*}$} \\
D(CHN(-2)) & -0.055222 & -0.229037 \\
& {$[-0.96766]$} & {$[-2.55710]^{*}$} \\
\hline
\end{tabular}

Note: $\quad$ BLR-Bengaluru CHN-Chennai Figures in square brackets are 't' values 
Table.4 Result of Granger Causality Tests for domestic seed coffee retail markets of Robusta cherry 'AB' coffee

\begin{tabular}{cccr}
\hline Null Hypothesis: & Observation & F-Statistic & Probability \\
\hline CHN does not Granger Cause BLR & \multirow{2}{*}{192} & 5.56732 & 0.0047 \\
BLR does not Granger Cause CHN & & 10.5683 & 0.0000 \\
HYD does not Granger Cause BLR & \multirow{2}{*}{192} & 3.97776 & 0.0208 \\
BLR does not Granger Cause HYD & & 8.28007 & 0.0004 \\
HYD does not Granger Cause CHN & \multirow{2}{*}{192} & 2.80906 & 0.0063 \\
CHN does not Granger Cause HYD & & 5.93616 & 0.0033 \\
\hline
\end{tabular}

Note: BLR-Bengaluru CHN-Chennai HYD-Hyderabad

Table.5 Co-integration for domestic seed coffee retail markets of Robusta cherry 'AB' coffee

\begin{tabular}{cccc}
\hline Error Correction: & D(BLR) & D(CHN) & D(HYD) \\
\hline CointEq1 & -0.188805 & 0.279249 & 0.249777 \\
& {$[-1.89336]^{*}$} & {$[2.40823]^{*}$} & {$[2.23105]^{*}$} \\
D(BLR(-1)) & 0.089499 & -0.024848 & -0.100503 \\
& {$[0.78917]$} & {$[-0.18843]$} & {$[-0.78935]$} \\
D(BLR(-2)) & -0.040857 & 0.186108 & 0.022911 \\
& {$[-0.36497]$} & {$[1.42968]$} & {$[0.18229]$} \\
$\mathrm{D}(\mathrm{CHN}(-1))$ & 0.096856 & -0.277541 & 0.152735 \\
& {$[1.13087]$} & {$[-2.78675]^{*}$} & {$[1.58839]$} \\
$\mathrm{D}(\mathrm{CHN}(-2))$ & 0.118586 & -0.164516 & 0.041708 \\
& {$[1.39068]$} & {$[-1.65916]$} & {$[0.43566]$} \\
$\mathrm{D}(\mathrm{HYD}(-1))$ & 0.099191 & 0.322799 & 0.277363 \\
& {$[0.94954]$} & {$[2.65741]^{*}$} & {$[2.36497]^{*}$} \\
$\mathrm{D}(\mathrm{HYD}(-2))$ & -0.115680 & -0.023205 & -0.053284 \\
& {$[-1.13191]$} & {$[-0.19526]$} & {$[-0.46439]$} \\
\hline
\end{tabular}

Note: BLR-Bengaluru, CHN-Chennai, HYD-Hyderabad; Figures in square brackets are ' $t$ ' values

Table.6 Transitional probability matrix for export of Arabica plantation coffee from India to different destinations (2000-01 to 2015-16)

\begin{tabular}{lcccccc}
\hline \multicolumn{1}{c}{ Destinations } & Germany & Italy & Belgium & Kuwait & $\begin{array}{c}\text { Russian } \\
\text { Federation }\end{array}$ & Others \\
\hline Germany & $\mathbf{0 . 5 0 4 2}$ & 0.0000 & 0.0854 & 0.0410 & 0.0000 & 0.3694 \\
Italy & 0.0000 & $\mathbf{0 . 5 9 4 7}$ & 0.1943 & 0.0000 & 0.0000 & 0.2110 \\
Belgium & 0.1819 & 0.1775 & $\mathbf{0 . 1 2 6 3}$ & 0.0299 & 0.1458 & 0.3386 \\
Kuwait & 0.0000 & 0.0000 & 0.0000 & $\mathbf{0 . 2 9 9 0}$ & 0.0000 & 0.7010 \\
Russian Federation & 0.0000 & 0.0000 & 0.0726 & 0.1636 & $\mathbf{0 . 1 4 4 0}$ & 0.6198 \\
Others & 0.2160 & 0.0883 & 0.1159 & 0.0289 & 0.0810 & $\mathbf{0 . 4 6 9 9}$ \\
\hline
\end{tabular}


Table.7 Transitional probability matrix for export of Robusta cherry coffee from India to different destinations (2000-01 to 2015-16)

\begin{tabular}{lcccccc}
\hline \multicolumn{1}{c}{ Destinations } & Italy & Spain & Belgium & Slovenia & Greece & Others \\
\hline Italy & $\mathbf{0 . 7 1 9 6}$ & 0.0000 & 0.0000 & 0.0000 & 0.0250 & 0.2553 \\
Spain & 0.3700 & $\mathbf{0 . 5 1 1 3}$ & 0.0000 & 0.0449 & 0.0738 & 0.0000 \\
Belgium & 0.0000 & 0.0000 & $\mathbf{0 . 4 5 5 0}$ & 0.2719 & 0.0000 & 0.2730 \\
Slovenia & 0.1380 & 0.2471 & 0.0000 & $\mathbf{0 . 4 6 7 0}$ & 0.1479 & 0.0000 \\
Greece & 0.7785 & 0.0741 & 0.1474 & 0.0000 & $\mathbf{0 . 0 0 0 0}$ & 0.0000 \\
Others & 0.0116 & 0.0671 & 0.0853 & 0.0191 & 0.0728 & $\mathbf{0 . 7 4 4 1}$ \\
\hline
\end{tabular}

One month earlier retail price Robusta cherry 'AB' coffee at Hyderabad seed coffee market alters the existing prices of Chennai and Hyderabad market seed coffee retail prices to the tune of 32 and 28 per cent correspondingly in positive direction.

The co-integration coefficients also indicated that (Table 5), any shocks in the seed coffee retail prices of Robusta cherry 'AB' coffee in Chennai and Hyderabad markets will get correct by itself within 28 per cent (about 8-9 days) and 27 per cent (about 7-8 days) of time period. Further, one month previous seed coffee retail prices of Robusta cherry ' $A B$ ' coffee at Chennai market alters the current prices of same market to the extent of 28 per cent in opposite direction. Similarly, one month previous seed coffee retail prices of Robusta cherry 'AB' coffee at Hyderabad market influenced on current prices at Chennai and Hyderabad seed coffee retail market prices to the extent of 32 and 28 per cent respectively in opposite direction. In other words, 100 rupees increase in one month previous seed coffee retail prices of Robusta cherry 'AB' coffee at Hyderabad market would increase the prices by 32 and 28 rupees respectively at Hyderabad and Chennai markets.

\section{Changing direction of export of Arabica plantation coffee}

Transitional probabilities of Indian Arabica plantation coffee exports are presented in table 6. The structural changes in the share of exports of Indian Arabica plantation coffee was analyzed through a first order Markov model. It is evident from results that the retention probability was highest in the Italy with 0.59 . The retention probability of Germany stood second with 0.50. This implies that the probability of retaining export share of Germany was 50 per cent. Similar interpretation could be made for Belgium, Kuwait and Russian Federation with probabilities of retention of 13, 30 and 14 per cent and 'other countries' with the probability of retention of 0.47 .

The probability of gains for Germany from Belgium was only 18 per cent. However, probability of loss to 'other countries' was 37 per cent. Further, probability of gains of Italy from Belgium was 18 per cent. On the other hand, its probability of loss to Belgium and 'other countries' were 19 and 21 per cent respectively. Similarly, probability of gains of Belgium from 'other countries' was 12 per cent, probability of loss were 34 per cent for 'other countries', 18 per cent each for Germany and Italy and 15 per cent for Russian Federation. Similarly, the probability of retention was 30 per cent for Kuwait during the study period but it lost 70 per cent of export share to 'other countries'. Russian Federation retained 15 per cent of its previous export share of Arabica plantation coffee from India during the study period. In the same period it lost lion share to 'other countries' i.e., 62 per cent and 16 per cent to 
Kuwait. The 'other countries' had retained probability of 47 per cent and same countries lost 22 per cent share to Germany during the study period.

The Markov chain process confirms the fact that the probability of retention of export share was less among major Arabica plantation coffee importers from India. Further, the probability of gains of major importing countries was less than the probability of losses to 'other minor importing countries'. The probability of more loss to 'other countries' implied the, the exports were moved from traditional importing countries to nontraditional importing counties.

Italy and Germany were the stable importers of Arabica plantation coffee with retention of 60 and 50 per cent share respectively during the study period. This retention may be because of the increase in consumption level of coffee during the study period in Italy and Germany. The ethnic populations residing in these countries are consumers of coffee from the time immemorial. Coffee is also consumed as a beverage for reduction of blood pressure in human beings. Therefore, India can relay more upon Germany, Italy for export of Arabica plantation coffee. Contrary results were reported by Veena (1994) for export of coffee from India indicated that India retained its market share to former West Germany, while USSR and Italy lost their share. Similar results were reported by Reddy and Samaya (2012) for export of total coffee from India. This result is well supported by the Nominal Protection Coefficient of export of Arabica plantation coffee from India (Table 2) wherein the NPV values are lowest with respect to Italy and Germany.

It would be necessary to give more stress on Belgium, Kuwait and Russian Federation as these are least loyal importers of Arabica plantation coffee from India as reflected by lower probability of retention values. The plans for export should be oriented towards these two countries and also plans should be formulated for stabilizing the export to other countries. The countries pooled under 'others category' had 47 per cent of the retention of its original share in the present study.

\section{Changing direction of Robusta cherry coffee export}

The direction of trade of Indian Robusta cherry coffee to different importing countries was studied by estimating the transitional probability matrix using the Markov chain framework. The transitional probability matrix presented in table 7 . The diagonal elements in a transitional probability matrix provide the information on the probability of retention of the trade. It is evident from the table that India had one of the most stable markets in Italy among the major importers of Indian Robusta cherry coffee as reflected by the higher probability of retention of 0.7196 i.e., the probability that Italy retains its import share over the study period to the extent of 72 per cent. Spain also retained reasonable export share of the commodity from its previous year to the extent of 51 per cent. Belgium and Slovenia were had retained moderate share to the extent of 46 and 47 per cent respectively. 'Other' countries showed better stability, which retained 74.41 per cent of their previous share. Greece appears to be most unloyal importer of Indian Robusta cherry coffee as the diagonal elements with respect to this country was zero.

Italy though excelled as most loyal country as far as Indian Robusta cherry coffee export is concerned, it also lost 25 per cent of its imports to other countries but it gained 78 per cent of India's export share of the commodity to Greece, 37 per cent of Spain and 14 per cent of Slovenia. Slovenia had retained 47 per cent of its original share but gained 27 per cent 
of import share of Belgium. Therefore, India can rely upon Italy, Spain and Slovenia for export of Robusta cherry coffee in near future. The NPC analysis (Table 2) also supports the findings of the Markov Chain analysis. The results are in line with findings of Reddy and Samaya (2012) for export of total coffee from India while contrary results were reported by Veena (1994) for export of coffee from India indicated that India retained its market share to former West Germany, while USSR and Italy lost their share.

The Markov chain process confirms the fact that the probability of retention of export share was less among major Robusta cherry coffee importers from India. Further, the probability of gains of major importing countries was less than the probability of losses to 'other minor importing countries'. The probability of more loss to 'other countries' implied the, the exports were moved from traditional importing countries to nontraditional importing counties.

It would be necessary to give more stress on Greece and Belgium as these are least loyal importers of Robusta cherry coffee from India as reflected by lower probability of retention values. The plans for export should be oriented towards these two countries and also plans should be formulated for stabilizing the export to other countries. The countries pooled under 'others category' had 74 per cent of the retention of its original share in the present study.

The seed coffee retail prices of Arabica plantation ' $A$ ' and Robusta cherry ' $A B$ ' coffee witnessed increased trend in the major markets studied over the study period. The retail prices of seed coffee of Arabica plantation ' $A$ ' and Robusta cherry 'AB' coffee at Chennai and Hyderabad markets are influenced by respective prices at Bengaluru market to a substantial extent but not vice-versa. Therefore, Bengaluru market is the prime price leader for marketing coffee in India. The Markov chain model proved the fact that probability of retention of export share was less among major Arabica plantation coffee importing counties. Italy is emerged as most stable major importers of Indian Robusta cherry coffee as reflected by higher probability of retention. In spite of negative export growth rate, Spain, Slovenia and Belgium are also emerged as moderately stable import destinations. Analysis further suggested that, Greece is most un-loyal importer of Indian Robusta cherry coffee during the study period.

\section{References}

Ashoka, N., Balachandra K. Naik and Vilas S. Kulkarni. 2014. Behavior of arabica coffee prices in international and Indian markets. Green Farming. 5(6): 11171121

Ashoka, N., Balachandra K. Naik and Vilas S. Kulkarni, 2016. Econometric analysis of wholesale coffee prices and exports from India. Economic Affairs. 61(3): 437-445.

Coffee Statistics, Various issues, Coffee Board, Bengaluru.

Reddy Vijaychandra, and Samaya Gairhe, 2012. Scenario of coffee in India - An overview. Research Journal of Agricultural Sciences. 3(1): 259-261.

Veena, U.M., 1992. An econometric analysis of Indian coffee export. M. Sc. (Agri.) Thesis, University of Agricultural Sciences, Bengaluru.

Venkatram, R., and Deodhar Satish, Y., 2005. Dynamic Demand Analysis of India's Domestic Coffee Market. Working paper, Indian Institute of Management, Ahemabad.

\section{How to cite this article:}

Ashoka, N., Balachandra, K. Naik and Anupama, G. 2017. Study on Export and Retail Price Behavior of Coffee Seed in India: An Econometric Analysis. Int.J.Curr.Microbiol.App.Sci. 6(9): 346-355. doi: https://doi.org/10.20546/ijcmas.2017.609.044 